\title{
COOPERATION IN INTERNATIONAL PROCEDURAL CONFLICTS: PROSPECTS AND BENEFITS
}

\author{
TAKESHI KOJIMA*
}

I

\section{INTRODUCTION}

Today the world's societies are closely woven in a global network. The activities of both citizens and businesses are conducted on an international scale, and the increasing division of work all over the world has globalized business activities. Certainly the interaction between diverse cultures peculiar to each region has enhanced and will continue to enhance the lives of the world's citizens. Yet, despite all the recent globalization, the world is still artificially bordered, both geographically and legally, by the traditional principle of territorial sovereignty. ${ }^{1}$

Against this background, consideration must be given to the various legal issues that arise during international dispute resolutions. International civil disputes show their legal complexity when parties attempt to resolve them through civil litigation. The litigation process always involves the laws of at least two countries. There are at least four basic questions that must be answered when international litigation takes place. First, how can the property involved in the dispute be preserved when there is insufficient information available prior to trial; ${ }^{2}$ second, in which country will the trial be held; third, in what manner will the procedural activities be carried out (service of the complaint, collection of evidence, enforcement of a foreign decision); and fourth, will the multiple complaints filed in several countries at the same time be coordinated.

International civil cases thus involve multinational elements. A coordinating treaty between the two or among the several states, as well as improvement of the domestic laws in each state is needed. The Hague Convention tackles these international issues, and the Convention's practical significance has been increasing of late. The need for international integration of civil procedure has been

\footnotetext{
Copyright (C) 1994 by Law and Contemporary Problems

* Professor of Law, Chuo University, Tokyo, Japan.

This is offered as a brief comment, not an academic article, on the papers presented at the October 1992 symposium conference entitled International Control of Civil Procedure: Who Benefits?

1. See generally GARY BORN \& DAVID WESTIN, INTERNATIONAL CIVIL LITIGATION IN UNITED States Courts (1988); Robert Casad, Jurisdiction IN Civil ACTION 1, 2 (2d ed. 1991).

2. Due to its great utility in this area of the law, the newly invented Mareva injunction has attracted much interest.
} 
strongly felt all over the world, particularly in the countries of Asia, North America, and Europe. ${ }^{3}$

The birth of an international treaty will be good news for all those involved in international civil disputes: including plaintiffs and defendants, third parties, witnesses, and holders of documents. At the very least, such a treaty will provide some measure of legal stability, regardless of the direction of its particular solutions and the sufficiency of its coverage. ${ }^{4}$ The foreseeability and predictability provided by the treaty are especially important in the areas of property and family law. The Hague Treaty will also be beneficial because the interaction of the countries involved will promote international mutual understanding. Hopefully, in the end, the Hague Treaty will curb excessive enthusiasm for territorial sovereignty and will advance procedural justice in the global context.

\section{II}

\section{DifFERENCES AND SIMILARITIES IN THE CIVIL PROCEDURAL SySTEMS OF THE WORLD}

The purpose of international control of civil procedure is-with "reason" (jōri), guided by fairness between parties, and the ideal of a speedy and fair trial $^{5}$ - to distribute jurisdiction properly and create a framework through which international disputes can be resolved smoothly. As the present situation is far from this ideal, much international control is needed. Because the basic philosophy of the role of the courts differs from country to country, ${ }^{6}$ however, international integration of the rules of civil procedure may prove too difficult to achieve. Therefore, instead of focusing on total international integration, we should direct our attention toward making progress within the framework of the world's various present systems.

A comparison of civil justice systems reveals great contrast between the continental and Anglo-American systems of civil procedure. Many people around the world have the impression that "the American procedure is the legal

3. The same is true with Japan; the feeling on this matter in Japan is quite different from what it was 20 or 30 years ago. In 1980, 147 services were sent to Japan from abroad; in 19912,069 (more than a 14-fold increase in 10 years). GENERAL SECRETARIAT OF THE SUPREME COURT, KOKUSAI SHIHO KYOJO SHITSUMU SHIRYO [HANDBOOK OF INTERNATIONAL JUDICIAL COOPERATION] 370 (1992) [hereinafter GENERAL SECRETARIAT].

4. The legal stability in this respect is a limited one in relation to the United States. For example, the interpretation of The Hague Evidence Convention of 1970 in the United States is, unlike that of Europe, that it does not place restrictions on the discovery of evidence but adds another method. See Paul D. Carrington, International Litigation in the Courts of the United States, in THE INTERNATIONAL SYMPOSIUM ON CIVIL JUSTICE IN THE ERA OF GlOBALIZATION: COLlECTED REPORTS 27 (Editorial Board of the ISCJ ed., 1993) [hereinafter INTERNATIONAL SYMPOSIUM]. For the view that many of the European countries take the stance that The Hague Evidence Convention preempts the rules of evidence of each nation, see Robert B. von Mehren, International Control of Civil Procedure: Who Benefits? 57 LAW \& CONTEMP. PROBS. 13 (Summer 1994).

5. See Judgment of October 16, 1981, 37 MINSHŪ 1224 (Japan) (the Malaysian Airlines Cáse).

6. For the great gaps in many respects on these aspects, see Arthur T. von Mehren, Recognition and Enforcement of Foreign Judgments: A New Approach for The Hague Conference?, 57 LAW \& CONTEMP. PROBS. 271 (Summer 1994). 
utopia for the plaintiff." Such impressions may result partially from unfamiliarity with foreign procedural models. It may also stem from the desire to provide a good excuse for the losing lawyer in an international controversy. Either way, attacks upon foreign systems are apt to be excessively intense, thereby escalating international legal frictions. ${ }^{8}$

\section{A. Procedural Rules}

Under the U.S. system of civil procedure, the parties to a dispute are able, at their own initiative, to gather a wide range of evidence by way of pretrial discovery. Under the continental system, on the other hand, the court takes the initiative in gathering evidence, pursuing discovery only when the case reaches the stage of evidentiary hearing, and even then to a more limited extent than parties under the U.S. system.

In the U.S. system, the jury, a group of lay people chosen at random, determines the facts of the case from the legally admissible evidence. In the continental system, however, the judge makes factual determinations according to his or her free evaluation of the evidence. Additionally, in the U.S. system, the burden of proof for finding the existence of a fact is based on the standard of a preponderance of the evidence. The continental system requires proof beyond a reasonable doubt or high probability. ${ }^{9}$

\section{B. Substantive Rules}

Under U.S. law, determination of damages is left largely to the discretion of the jury. This system sometimes produces huge jury awards, which courts usually affirm later because judicial control on this point is strictly limited. In the continental system, on the other hand, damages are determined uniformly, based on conventional compensatory methods that have been established in practice.

In the United States, a jury may award punitive damages, which force the defendant to pay far more than the actual damages incurred by a victim. In contrast, in the continental system, no punitive damages exists. The purpose of damages is strictly to compensate the plaintiff for the loss caused by the defendant's action.

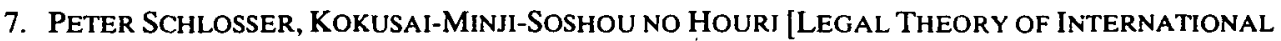
Civil PROCEDURE] 11 (Takeshi Kojima ed. \& trans., 1992).

8. One example is when a lawyer, who is tactically prolonging the arbitration case, changes his tactics and blames the arbitrator for his way of handling the arbitration when the lawyer is criticized by his client because the delay is working against him.

9. Perspectives on Civil Justice and ADR: JAPAN AND the United States 146 (Takeshi Kojima ed., 1990). 


\section{Legal Profession}

U.S. lawyers constitute a large percentage of the world's total number of lawyers. ${ }^{10}$ There are far fewer lawyers on the continent, especially in Japan, where the number of practicing lawyers is very small, only about $14,000 .{ }^{11}$

Legal expenses in the United States seem exorbitant by Japanese and European standards. In the U.S., contingent fee arrangements are very popular. In cases where hourly fees are charged, activities like discovery cause legal fees to become very high. In contrast, on the continent, contingent fee arrangements are almost universally prohibited, ${ }^{12}$ and legal fees are regulated by law and the court. ${ }^{13}$

Although U.S. lawyers are widely allowed to advertise their legal services, the practice is severely restricted on the continent. In Japan, although the advertising prohibition was partly lifted in the late 1980s, Article 10 of the Code of Ethics for Lawyers still prohibits "advertisements that degrade the decency of the lawyers" and bar associations prohibit legal advertising via billboards, neon-signs, and balloons, ${ }^{14}$ as well as through television and radio. ${ }^{15}$

One interesting question is how differences among various countries' legal systems affect the litigation behavior of their citizens and businesses. Many people believe that the U.S. system and the activities of U.S. lawyers are responsible for creating a litigation explosion that has threatened the breakdown of the U.S. liability insurance industry. Japan has recently considered the impact of reforming the substantive rules of product liability law. In 1992, the Economic Planning Agency of Japan sent an investigating group to Europe to conduct a field survey. According to the survey, in each European country studied, legal experts do not believe that introducing strict liability in their countries will bring about the flood of product liability litigation that has occurred in the United States. The reasons are simple: the underlying legal systems of the European countries differ greatly from the U.S. system, and European lawyers do not behave like their U.S. counterparts. ${ }^{16}$ English lawyers' behavior is not different on this point. ${ }^{17}$

10. Maurice Rosenberg, Courts and Alternative Dispute Resolution in the United States, in INTERNATIONAL SYMPOSIUM, supra note 4, at 465.

11. Takeshi Kojima, Dispute Resolution systems and Legal Culture, in INTERNATIONAL SYMPOSIUM, supra note 4 , at 522 .

12. One exception is Greece. In Japan, arrangements called "partially contingent fees" prevail Accordingly, a client pays one-half of the fees to the lawyer in the beginning and pays the remaining half only when he wins in court. See, e.g., Lawyers Fee Standard (Rules of the Japan Federation of Bar Associations) art. 18 (1975).

13. Among continental countries, Japan is the exception. In Japan the standard of attorney fees is self-regulated by bar associations rather than statutes and courts.

14. Rules For AdVERTISEMENT OF LAWYERS' LeGAl SERVICES art. 4.

15. A limited use is permitted for newspapers. Id.

16. The Economic Planning Agency, Seizoubutsu Sekinin ni kansuru Oushu Chousa HOUKOKU 3 (1992) (survey report on European product liability law and practice).

17. Id. 
The structure of a country's judicial system and the behavior of a country's lawyers determines how its substantive laws will function. Given such differences in each legal system, it is not surprising that parties are increasingly inclined to shop around for a favorable forum for litigation, thereby exacerbating international judicial conflicts.

III

\section{INTERNATIONAL JUDICIAL CONFLICTS AND WAYS TO BREAK THROUGH THE PRESENT DifFICULTIES}

So far this article has described fundamentals of the international conflicts over international jurisdiction and extraterritorial procedural activities, while focusing on the characteristics of the U.S. legal system. The causes of conflict can be found, in varying degrees, in every country's legal system. ${ }^{18}$

Judicial conflict between the United States and Europe has brought about the creation of blocking statutes and various counteractions such as negative declaratory judgments, injunctions for blocking the execution of foreign judgments, and damage suits against frivolous litigation. Such measures have attracted much attention all over the world. Those statutes and actions in Switzerland, France, and Germany are clearly blocking in nature, and it is indeed notable that the United Kingdom has taken the same stance. ${ }^{19}$ Japan, too, has given a similar response, though in a more restricted form. ${ }^{20}$

In the Kansai Tekko case, a U.S. enterprise sued Kansai Tekko, a Japanese corporation, in the United States. ${ }^{21}$ Kansai Tekko then filed a suit in Japan seeking a negative declaratory judgment that it had no duty to reimburse the U.S. company. The resulting decision rendered in favor of Kansai Tekko clearly indicated that the Japanese court had the international jurisdiction in the case and that Kansai Tekko had no such duty of reimbursement. ${ }^{22}$ The U.S. company later sought the execution of the favorable U.S. decision in Japan. The Osaka District court held that the Japanese decision previously rendered in favor of Kansai Tekko had become part of the "public order" under Article 200 of the Code of Civil Procedure. Therefore, a Japanese court with proper jurisdiction would have cause to block the execution of the U.S. decision in

18. A foreign defendant must face various disadvantages such as the use of foreign languages, the application of foreign procedural laws, and the need for double legal representation.

19. See Rolf STÜRNER, KoKUSAI SHIHO MASATSU 35, 39, 94 (Ichiro Kasuga trans., 1992). E.g., Economic Competition Act $(1956, \mathrm{Nem})$, Loi rélative à la communication des documents et reinseignements d'ordre économique, commercial ou technique à des personnes physiques ou morales étrangères (1980, Fr.), Protection of Trading Interests Act (1980, U.K.).

20. The relevant Japanese law holds that a lawyer representing a foreign defendant may interview a witness in Japan, so long as it is voluntary, but that if it accompanies any sanction, it cannot be permitted as an infringement of the sovereignty. According to this interpretation, the blocking statutes are not necessarily needed. See Yoshimitsu Aoyama, Problems of International Litigation, in INTERNATIONAL SYMPOSIUM, supra note 4, at 58.

21. The U.S. court held both companies liable for product liability damages.

22. Judgment of Oct. 9, 1973, Osaka Dist. Ct., 728 Hanrei Jiho 76 (Japan). On the contrary, the judgment of Jan. 29, 1991, 1390 Hanrei Jiho 98 (Japan), denied a jurisdiction of a Japanese court in a similar case. 
Japan. $^{23}$ These twin Japanese decisions opened a means for international counterlitigation. However, a later lower court decision dismissed the case due to the lack of international jurisdiction in a more or less similar fact situation. ${ }^{24}$

Apprehensions about the "poison" that differences in legal systems and cultures produce further promote judicial conflicts like the one just described. First, the peculiar institution of the U.S. jury provokes international judicial conflict. Although the jury system reflects democratic values in that one's societal peers determine the outcome of a trial, many people feel that emotional factors affect a jury verdict, diverting the jurors from the course that the law requires them to follow. To a foreign defendant who is afraid of losing a case, this element of the U.S. legal system can seem unbearably prejudicial. The overall effect is a general feeling of antagonism toward the jury system. Though some Japanese companies view U.S. juries with hostility, it must be recognized that a persecution complex may underlie such feelings. However, a director in the law department of a large Japanese company frankly states that his experience and personal surveys have produced no evidence showing U.S. juries to be biased against Japanese business. ${ }^{25}$

Second, many on the continent similarly fear the punitive damages often awarded in U.S. courts. The availability of punitive damages when no actual damage has been caused has led legal experts on the continent to think that punitive damage suits are an abuse of the litigation process. The negative evaluation of punitive awards dominates the academic communities of Europe and Japan. And, private antagonism toward U.S. litigation can easily become public sentiment. In fact, a Japanese district court judgment recently declared that a foreign decision granting punitive damages cannot be executed in Japan. The court held that even if there were a legitimate cause for awarding punitive damages in the case, the foreign decision ordered such a huge amount of damages that it was too severe in view of common sense, equity, and public policy. ${ }^{26}$ The district court refrained from categorically denying enforcement of U.S. punitive damage decisions. According to this decision, if a U.S. judgment granting punitive damages utilized some precautions like a special verdict and well-prepared court records, and awarded a more reasonable amount of punitive damages, it might very well be enforceable in Japan today. However, on appeal, the Tokyo High Court foreclosed enforcement of the decision for punitive damages categorically on the ground that the decision is of a criminal rather than civil nature. ${ }^{27}$

23. Judgment of Dec. 22, 1977, Osaka Dist. Ct., 361 Hanrei Times 127 (Japan).

24. Judgment of Jan. 29, 1991, 1390 Hanrei Jihō 98 (Japan).

25. My interview with a director of the legal department of a major auto maker.

26. This case took place in the following circumstances: a U.S. partner of a Japanese company that had failed in its advancement in the United States filed a damage suit against the headquarters in Japan and the subsidiary in the United States on grounds of fraud. The jury ordered the headquarters of the company in Japan to pay $\$ 420,000$ as compensatory damages and $\$ 1,120,000$ as punitive damages. CIVIL Procedure CODE art. 200 § 3; Civil Execution Law art. 244; Decision of Feb. 18, 1991, 1376 Hanrei Jihō 79.

27. Decision of Aug. 28, 1993, 823 Hanrei Times 126 (Japan). 
Third, differing attitudes about proper behavior for lawyers also contribute to international conflict. U.S. lawyers are often viewed by their continental counterparts as overly competitive and commercial. ${ }^{28}$ Japanese lawyers assert they make decency and dignity of the profession high priorities; in Japan, a lawyer's primary duty is to act for "the social justice and the protection of human rights." ${ }^{29}$ Japanese lawyers are appalled by such aggressive lawyering behavior as U.S. lawyers flying overseas to obtain clients at the scene of an industrial accident. The European countries seem to share this feeling, too.

Fourth, continental litigants are also wary of the U.S. legal system because they feel its judiciary wields too much power. Many foreigners believe that U.S. civil litigation fulfills the functions of policy formation and social reformation in addition to the more traditional judicial functions of dispute resolution. This means that U.S. courts take into account public policy considerations beyond the protection of the particular rights of the parties to the litigation. For example, substantive regulations like antitrust and securities laws, and procedural devices like class actions make private lawsuits powerful vehicles for social change in the United States. Thus, U.S. courts and the private parties in lawsuits play roles functionally equivalent to those played by administrative agencies on the continent.

These four factors demonstrate how international businesses, especially conglomerates, must cope with internationally diverse legal environments. The businesses of Europe, Japan and the United States evaluate the diversity differently, however.

U.S. businesses think that Japanese companies have an advantage, because in Japan there are few legislative protections for consumers and investors. The Japanese believe that excessive litigation will, in the long run, spoil the interests of consumers, investors, and citizens in general, and that it is the U.S. legal system which needs reform. ${ }^{30}$ This difference of opinion underlies the controversy over product liability. The conflict on this point is so deeply rooted in fundamental legal policy and philosophy that it is not surprising that continental legislators delayed their decisions about whether to introduce strict product liability. Such a dichotomy in basic social ideas makes it very difficult for us to reach international agreement on this point.

28. Such view shared by a group of lawyers is described in the report by the Commission on Foreign Solicitors Law. Gaikoku Bengoshi Mondai Kenkyukai, Hokokusho (Ministry of Justice and Japan Federation of Bar Associations) (1993).

29. Practicing AtTorney Law art. 1, No. 205 (1949) (Japan).

30. The Agenda for Civil Justice Reform in America rendered by the President's Council on Competitiveness makes it clear that there exists a similar apprehension in the United States. The critics of the U.S. interpretation in Japan and Europe may be somehow encouraged by this report. See Akihiko Kobayashi, Beikokuno Minji Shiho Seido Kaikaku Hou-an no Gaiyo, 498 NEW BUS. L. 3 (1992). 


\section{IV}

\section{POSSIBLE SOURCES FOR COORDINATING INTERNATIONAL JUDICIAL RELATIONS}

International judicial conflicts are not limited to problems of international civil procedure. More fundamentally, conflict results from different approaches toward the proper role of the bar and the proper scope of substantive laws. This more basic clash concerns issues of legal justice and social fairness, matters beyond simple questions of territorial sovereignty.

Our analysis must therefore transcend the controversy over excessive jurisdiction and infringement of sovereignty, and inquire as to what the ideal form of international judicial cooperation should be. Each nation should stop pointing fingers. Rather, the global community must identify the merits of each system and seek ways to optimize international dispute resolution by integrating those merits. As a premise for this cooperation, there must be a sharing of the wisdom - a view toward pluralism so that each nation may appreciate the merits of every other's system. ${ }^{31}$

In any case, since the law and the judicial system exist for the good of citizens and businesses, each nation should, for the benefit of its constituents, discharge the burden of setting out fair and effective international principles and rules in its own judicial system. Countries should not lose sight of the fact that neither the pride of the nation nor the professional interest of the lawyers is paramount. Rather, the interests of the citizens and businesses should determine the proper make-up of such principles and rules. International control of civil procedure should center on these fundamental ideas.

Then, each nation, in its own efforts toward international control of civil procedure, should try to further the integration of its procedure as much as possible and at the same time introduce a flexible device of coordination in the area where such an integration cannot be carried out. In any case, in promoting international control of civil procedure, nations need to share the key concepts on which various ideas may have been based in order to structure a firm foundation for progress.

\section{A. International Jurisdiction}

The two most important goals of a civil justice system are effective court access for the plaintiff and guarantees of fair procedure (due process) for the defendant. These two concepts are the twin brothers of the "Goddess of Justice." The due process concept, which was first established in U.S. case

31. The United States is a nation where the judiciary is dominant. However, in the United States, there is a vigorous tradition of populism as well. Indeed, some flavor of direct democracy and trial by peerage still lingers. On the continent the executive branches are dominant, and the judiciaries are carried by bureaucrats. 
law, ${ }^{32}$ should always serve to restrict an excessive expansion of international jurisdiction.

Because the concepts of effective access and fair procedure are abstract benchmarks, specific working standards must be formulated by balancing the various interests in particular cases. In searching for a proper balancing approach, we must be careful to avoid being trapped in a common pitfall. For example, Japanese courts determine international jurisdiction on a flexible caseby-case basis, tailoring the domestic rules of venue with reason and equity, taking into consideration the "special circumstances" of each case. These special circumstances usually work to negate international jurisdiction. If the determination of jurisdiction is more complex and time consuming due to the consideration of special circumstances, the predictions of the parties become more unreliable..$^{33}$ Too fine a balancing approach is apt to delay consideration of a case and produce uncertain results. Much attention should be paid to prevent these defects as much as possible.

Two coordinating concepts must be considered in determining international jurisdiction. The first is forum non conveniens, and the second is jurisdiction by necessity, that is, an emergency creation of international jurisdiction. First, under the concept of forum non conveniens, courts, although having otherwise appropriate jurisdiction over a dispute, may dismiss the suit if a more convenient forum for the parties exist. In determining the appropriate jurisdiction, courts must weigh private interests, such as the parties' access to evidence, along with public interests, such as the burden on the court in trying the case. The concept of forum non conveniens is well established in AngloAmerican law, ${ }^{34}$ and there is a possibility that Japan could embrace it as well. The Taiwan Entou Airlines case $\mathrm{e}^{35}$ provides a recent example in Japan of a suit dismissed as improper due to the unavailability of essential evidence. The suit arose out of a plane crash in Taiwan and involved claims for damages by eighteen plaintiffs, including the bereaved of a famous female writer, Kuniko Mukoda. The Japanese court dismissed the case on the ground that it could not set up an international jurisdiction when essential evidence was in Taiwan and, thus, not obtainable through judicial cooperation due to the lack of diplomatic relations between the two countries. ${ }^{36}$

Second, jurisdiction by necessity is a doctrine of French origin whereby a court may create international jurisdiction in a case where, under the circumstances, no other nation's court would otherwise have jurisdiction to entertain the suit. In these situations, the availability of international jurisdiction depends

32. Cf. von Mehren, supra note 4, at 15 .

33. Masato Dougauchi, Rippouron toshiteno Kokusai Saiban Kankatsu, 91 KoKUSAIHOU GAIKoU ZASSHI No. 2, at 8 (1992).

34. There are some U.S. jurisdictions that do not allow the theory of forum non conveniens, for example, Texas. Carrington, supra note 4, at 35; see also GENERAL SECRETARIAT, supra note 3, at 9.

35. Decision of June 20, 1986, Tokyo Dist. Court, Hanrei Jihou, No. 1196, at 87; Hanrei Times, No. 604 , at 18.

36. Id. 
on the concrete facts and cannot be determined in the abstract. It would also be appropriate to allow some judicial discretion on a case-by-case basis to stay the procedure temporarily or to dismiss the litigation upon the fulfillment of certain conditions. ${ }^{37}$

\section{B. Discovery}

Discovery has become a strong instrument of evidence collection in U.S. civil procedure, but it is almost foreign to the continental countries. The unique nature of this mechanism consists of the parties swiftly gathering evidence by themselves without the intervention of a judge. Because discovery is backed by judicial sanctions, it is actually a use of public authority disguised as a private method. Thus, discovery is nimble and can enter the territory of other countries. The scope of discovery extends to all information that may potentially lead to the uncovering of other admissible evidence. Though several privileges to reject disclosing evidence exist, they are quite narrow. Furthermore, the sanction of contempt of court forcefully controls refusals to disclose evidence. ${ }^{38}$ Another controversial requirement of U.S. discovery is that in taking a deposition, each party examines the witness. This system collides with the continental system in which a judge examines the witness. Thus, despite a persistent assertion by the United States that voluntary discovery is not an exercise of sovereignty, other countries still criticize it as an illegal infringement of their sovereign jurisdiction.

The discovery system should not be discarded simply because it runs counter to the continental system, however. It must be evaluated on its own merits and functions. The U.S. system enables the parties to exchange evidence prior to trial and rectifies situations where evidence is held or gathered by only one party. The exchange of evidence through the discovery device raises the rate of successful settlement of disputes. ${ }^{39}$ On the other hand, it can also be predicted that the overall discovery system results in a higher litigation rate. ${ }^{40}$ More people may start an action to acquire evidentiary information and possibly to reach settlement. Given the beneficial role that discovery plays in assuring fairness in the settlement process, however, it is unreasonable to dismiss this

37. For instance, in the Bhopal disaster case, the suit was dismissed on conditions that the defendants in the United States be subject to discovery and that those in India not be denied due process. In re Union Carbide Corp., 809 F.2d 195 (2d Cir. 1987) (Gas Plant Disaster at Bhopal, India In Dec. 1984).

38. For instance, a Swiss company was imposed a fine of $\$ 50,000$ a day for its disobedience to the court order of subpoena duces tecum in Marc Rich \& Co. v. United States, 707 F.2d 668 (2d Cir. 1983), and DeutscheBank was imposed a fine of $\$ 150,000$ a day for the same reason in In re Grand Jury, 550 F. Supp. 24 (W.D. Mich. 1982). See STÜRNER, supra note 19, at 7.

39. For example, the Texas and Ohio cases that finally reach trial represent only about $0.3 \%$ of the entire number of disputes. Charles Thensted, Litigation and Less: The Negotiation Alternative, 59 TUlANE L. REV. 78 (1984).

40. Kojima, supra note 11 , at 509 . 
system out of hand. The cardinal point is to prevent its abuse while best capturing its merits. ${ }^{41}$

\section{Jury System}

The jury system is generally perceived to embody democratic political values, deeply rooted in U.S. culture, and it will not be abolished in the near future. ${ }^{42}$ Some people have encouraged introducing the jury system in Japan, partly because a former Chief Justice of the Supreme Court has instructed on the study of that possibility. ${ }^{43}$ Regardless of whether other nations like a jury system, the reasonableness of the jury system cannot be denied, and one should respect the choice of the United States on this point. Even if the jury system serves to increase litigious behavior in a country where such a system is used, it is advisable to face this phenomenon in a calm manner and evaluate it having in mind the ultimate interest of citizens.

\section{Service of the Complaint}

It seems difficult for a continental lawyer to justify and support the U.S. method of serving the complaint. Under the newly introduced rule, notice by any adult nonparty or by registered mail suffices for service of process. Professor Smit points out that because this method is not an official activity and functions only to give notice to the other party, the criticism from Japan and Europe cannot be justified. ${ }^{44}$ However, from the continental perspective, the service of the complaint is one of the basic requirements for starting the official litigation process. The service is, thus, by definition, not a private activity but part of the official litigation act. As a result, service of process achieved by sending notice to a defendant in a foreign country infringes upon the sovereignty of that territory. The crux of what lies behind this formalistic categorization is not that an actual service has been made in a particular case, but that service in the hands of private parties is in general uncertain. It is a matter of procedural public policy that only officially recognized types of activities designated by relevant laws can assure the certainty needed for the litigation process.

41. In this respect, the Restatement takes important steps toward setting up some reasonable restrictions on discovery. The court may allow the discovery of the evidence that has been specifically particularized, after it has scrutinized the consistency of the arguments of the parties. Sanctions against the refusal should be mitigated to a reasonable extent. See Robert B. von Mehren, Transnational Litigation in American Courts, 1984 DICK. J. INT'L L 43.

42. Geoffrey Hazard, THE Significance OF American Civil Procedure IN THE UNIFICATION OF PROCEDURE FOR ADJUdiCATION OF TRANSNATIONAL LEGAL DisPUTES 6 (1992) (report for the Project on the roles of Courts at the Institute of Comparative Law in Japan).

43. Former Chief Justice Koichi Yaguchi's remarks at the press conference, Asashi Shinbun, May 2,1989 , at 3 .

44. Hans Smit, International Control of International Litigation: Who Benefits?, 57 LAw \& Contemp. Probs. 25, 27 (Summer 1994). 


\section{$\mathrm{V}$ \\ EXPECTATIONS FOR THE ACTIVE COOPERATION OF INTERNATIONAL LAWYERS}

Civil litigation accompanies some negative impacts, such as the financial burden on taxpayers. On the contrary, international arbitration does not cause much burden to taxpayers because the cost for setting it up is as a rule paid by the parties. To be sure, there could be some litigations for repealing the arbitration award, but their number is in practice very low.

Arbitration institutions in each nation tend to compete for arbitration cases, perhaps in an effort to expand the share of legal services handled by international lawyers. Because a procedure created in arbitration is on the basis of consensus between the parties, it is comparatively free from the restraints of each nation's legal culture. A group of international lawyers, rather than the laws of each country, exercises great influence on the way arbitration works. Thus, the arbitration, wherever it may be held, will be relatively neutral, that is, its procedural and substantive aspects will not favor either country too much. ${ }^{45}$ In order to avoid the international frictions that may arise in determining international jurisdiction and in the course of litigation, arbitration is a far superior method to litigation, given its universality in procedure.

However, there is a limitation on arbitration in that it can only be carried out with the consent of the parties. Due to this functional constraint, civil procedure still plays a great role in resolving disputes. As the cooperation network among international lawyers grows, the risks of international judicial conflicts over civil procedure will be reduced. In the international legal community, lawyers of one country are visiting other countries to do business there at an increasing rate. ${ }^{46}$ In addition, international law firms have set up several branches in and outside their own countries. ${ }^{47}$ Therefore, whatever country becomes the forum for litigation, these conditions will enable international conflicts in civil procedure to be avoided to some extent.

Under these circumstances, the significance of international conflicts over the determination of international jurisdiction as well as over extra-territorial litigation has decreased, at least in the context of competition among international lawyers. Although a foreign lawyer may represent a party in internation-

45. Takeshi Kojima, Kokusai Chusai to Hou-Bunkateki Churitsusei, 1 Minı TETsuzukiHOU NO SASSHIN 591 (1991) (The Celebration of Professor Akira Mikajuki's 70th Birthday).

46. Foreign lawyers are prohibited from employing Japanese lawyers or entering into partnership with them in Japan. Foreign Law Solicitor Act art. $49 \S \S 1,2$. Since article 49 has been severely criticized by the lawyers of the United States and Europe, the commission set up by the Ministry of Justice and the Japan Federation of Bar recommended permitting foreign lawyers to enter joint enterprises (kyodojigyo) with Japanese lawyers under certain conditions on September 30, 1993. The Hosokawa cabinet decided to amend the Act along the lines of the Commissions recommendation on April 19, 1994. The Act was finally promulgated on June $29,1994$.

47. It is prohibited for a Japanese law firm or a lawyer to have more than one office. Practicing Attorney Law art. $20 \S 3$. 
al arbitration in Japan, ${ }^{48}$ such is not possible in civil litigation there. ${ }^{49}$ In spite of these limitations, as more countries establish the system of foreign law solicitors, the scope of their activities will expand, and the opportunities for lawyers to get into foreign markets directly or indirectly will increase.

One of the important problems in international legal business is the unbalanced competition between U.S. lawyers and those of other countries. Because the United States has built a strong worldwide network of business due to the accumulation of prior experience and economies of scale, and other countries have weak business structures, the United States is sweeping the international market for legal business. This fact admittedly concerns not only the Japanese legal profession but also German lawyers, once thought to be one of the strongholds of the legal academism in the world. ${ }^{50}$ The U.S. legal culture is structured upon pioneer innovation in economic legislation, confidence in maintaining legal traditions, and the accumulation of working knowledge in practice. In addition, many U.S. lawyers have been trained at powerful national law schools that can be described as today's "Universita di Bologna." Because of this vigor and vitality in the U.S. legal culture, the lawyers there are clearly gaining superiority over others in the world. If the lawyers of Japan and Europe are able to improve their caliber and establish an equal relationship for cooperation with U.S. lawyers, then the future of a global system of dispute resolution will improve with each legal culture absorbing the meritorious factors from the others.

Of course, there is a limit to the amount of convergence in that various nations will likely retain important procedural differences in the foreseeable future. For example, adoption of the cross-examination system is one of the issues upon which agreement will remain difficult. In this respect, some flexible device for coordination is needed. When France ratified the Hague Evidence Convention, ${ }^{51}$ it also adopted, in its amendment to the Code of Civil Procedure in 1975 , cross-examination and verbatim transcription systems that specifically mirror the deposition-taking methods of the United States. ${ }^{52}$ Only with the premise of broad cooperation will international control of civil procedure contribute to securing worldwide legal harmony among responsible citizens and the business enterprises.

48. A foreign lawyer admitted as a "foreign law solicitor" can represent a client in arbitration. The official interpretation by the resolution of the Board of Directors at the Japan Federation of Bar Associations of Mar. 16, 1990.

49. Foreign Law Solicitors Act art. 3, $§ 1$ (No. 66 May 23, 1986).

50. Stürner, supra note 19 , at 68 .

51. Convention on the Taking of Evidence Abroad in Civil or Commercial Matters, opened for signature March 18, 1970, art. 2, 23 U.S.T. 2555, 847 U.N.T.S. 231 (accepted by France with reservation on Aug. 7, 1974).

52. See von Mehren, supra note 4, at 23. 


\section{A. Conflicts over International Jurisdiction and Extraterritorial Procedural Acts}

Upon consideration, international judicial conflicts are essentially conflicts over jurisdiction with the sovereignty of each nation hanging in the balance. The issues can be considered in two parts. The first issue is to determine which nation's court has international jurisdiction. The second issue concerns extraterritorial procedural acts (sosho koi), namely in what method and to what extent procedural acts such as the collection of evidence and service of litigation documents can be undertaken extraterritorially.

Extraterritorial procedural acts raise theoretical questions, which perhaps may dominate the practical concerns. For instance, in continental law, the collection of evidence and the service of procedural documents represent official exercises of judicial power. The U.S. system, however, essentially views serving notice as a private act. For example, the purpose of the service is to give notice to the other party ${ }^{53}$ thus, once notice is given, the purpose is fulfilled. Under this system, the requirement is simple, and the nature of the act for giving the notice demands no further inquiry. On the other hand, in continental law, the service constitutes more than notice-it is a formal official act. Therefore, service by direct mail, if conducted in a foreign country, infringes upon that nation's sovereignty. Thus, various countries have taken steps to preclude such violations. Germany has made a declaration of reservation as provided in Article 10(a) of the Hague Service Convention. ${ }^{54}$ Japan's approach is simply to regard service by mail as not having the effect of a procedural act. Even though Japan treats the issue lightly, the message is clear in Japanese minds. However, the intended message has puzzled foreign, especially U.S., lawyers who believe that Japan should have made the Article 10 reservation, if the message is of such a nature. ${ }^{55}$ Taking these considerations into account, one should not be misled to believe that theory is at the heart of the issue of extraterritorial procedural acts. Because a policy determination that legal certainty must be assured in the litigation process underlies the continental system, practical considerations regarding such acts are more relevant.

Next let me consider the issue of extraterritorial procedural acts from an economic perspective, by focusing on the major players in judicial conflicts. For example, a damage suit following an airplane accident pits the airplane and insurance companies against the victims of the crash. Product liability suits, on the other hand, involve business enterprises in litigation against their consumers. In such cases, it is usually the defendant businesses that criticize the "infringement of the sovereignty" by the foreign court and the foreign plaintiff. When

53. Smit, supra note 32, at 27.

54. Convention on the Service Abroad of Judicial and Extrajudicial Documents in Civil or Commercial Matters, opened for signature Nov. 15, 1965, art. 2, 20 U.S.T. 361, 658 U.N.T.S. 163 (accepted with reservation by Germany on April 27, 1979).

55. Bruno Ristau, Service of Process in Foreign Countries under the Hague Service Convention, UNITED STATES/JAPAN COMMERCIAL LAW AND TRADE 460 (Valarie Kusuda-Smick ed., 1989). 
businesses try to block the enforcement of a foreign judgment, they assume the role of the plaintiff or the defendant. In any event, the presence of the international conglomerates is very impressive in this field. ${ }^{56}$

While these broad patterns of behavior are readily apparent, in practice, the situation is far more complex. Thus, it is very important to pay attention to the particular interests of the parties involved in judicial conflicts. However, in drawing conclusions, one must be careful not to forsake the consistency of standards by focusing too heavily on the balancing of particular interests.

\section{B. Underlying Legal Values}

The concept of fairness is integral to any discussion of legal values. Access to justice and fair process represent the core legal values in international civil procedure. These values play important roles that extend well beyond technical regulation of litigation.

The importance of fairness is closely related to the phenomenon of constitutionalization of civil procedure law. The primary elements instigating change ultimately trace back to developments in U.S. case law. These two concepts, access to justice and fair process, may by nature often conflict; therefore, the task to coordinate them would be very complex and difficult if it were to be strictly discharged. In Japan, since the Supreme Court decision in the Malaysian Airlines case ${ }^{57}$ considered reason as the main criterion, the resulting trend remarkably has been for the lower courts to apply a delicate balancing test in reaching judgments. In one respect, Japanese courts advanced toward the ideal distribution of international jurisdiction, while the role of rules of domestic venue is declining. As a result, interests reflecting the particular circumstances of each case carry increased weight in the consideration of a case. Thus, it has become very critical in Japan to choose between two alternatives: either apply the rules that have been conventionally developed in the domestic venue with some modifications or employ the balancing test in each particular case. In the future, the rules embodying settled principles must be firmly followed in routine cases, while jurisdiction by necessity and forum non conveniens can be employed in exceptional cases. We should accept this direction as the most balanced and appropriate course. In the long run, we should strive to establish the legal stability that secures predictability for the parties. However, at the moment, with reason as the benchmark, flexibility must be granted in order to form appropriate standards by which to balance the relevant interests.

In this gradual process of development, we have to bear in mind that the key concept in international civil procedure is the effective protection of right and proper interest. In the era of globalization, we have to achieve this not only in domestic courts but also in foreign courts. The stage for legal protection tends to be worldwide, so that priority should be given to parties' interests rather than

56. Smit, supra note 32, at 29.

57. Judgment of Oct. 6, 1981, 37 Minshū 1224 (Japan). 
state interests. Worldwide protection of effective justice is the inevitable responsibility of each country in the present day world.

\section{The Legal Environment Underlying the Judicial Conflicts}

The fierceness of the judicial conflicts often stems not from the particular suits, but rather from the conflicts of civil procedure that underlie them. The crux of this issue is the distribution of international jurisdiction not among the homogenous procedures, but rather among the heterogeneous ones.

The issue of international jurisdiction, as the von Mehren report points out, ${ }^{58}$ involves complex elements of cultural conflict among varying procedures. Moreover, the different nature of each nation's procedure originates not only from attempts at efficiency but also from each nation's legal culture and political values. The jury trial, cross-examination, and punitive damages, to name a few, illustrate the complex nature of this issue. International differences in civil procedure cause frustration and anxiety for the members of the legal profession who have to litigate in a foreign country. They also affect the financial interests of the parties, especially the defendant. Punitive damages have caused serious shock waves because of their quasi-criminal nature and potentially exorbitant amounts. In order to obtain the cooperation necessary to reach international agreement on this issue, the United States must assure the numerical propriety of punitive damage awards.

D. A Road to International Cooperation: Making a Treaty or Reforming the Domestic Law?

The judicial conflicts between the United States on one side and Japan and Europe on the other have cast their shadow on the Hague Convention. A controversy of interpretation over whether the Convention permits the U.S. method of serving documents and collecting evidence exists. ${ }^{59}$ The forceful view in Europe argues for the Hague Convention's exclusivity, while the counterpart in the United States advocates its supplemental nature. The latter view deplores the stance taken by the U.S. Supreme Court that the Hague Convention excludes rather than supplements U.S. methods, and thus argues that if the Court continues to take the same stance, the United States should leave the Convention. ${ }^{60}$

Needless to say, behind the international judicial conflicts remain multiple layers of interests or concerns: the sovereignty of a nation, the financial interests of the parties, the perception of the role of litigation, the traditions of legal culture, and socioeconomic policy. These interests are so intricately intertwined that the reform of domestic law will necessarily face numerous obstacles. However, primary consideration should be given to providing parties a meaningful day in court, that is, to ensuring procedural justice between the

58. von Mehren, supra note 4 , at 20.

59. Smit, supra note 43 , at $27-32$.

60. Id. at 40 . 
parties, access to court, and fair process. In this context, my impression is that U.S. lawyers tend to emphasize the plaintiff's access to court, while continental counterparts are eager to protect procedural guarantees for the defendant. That is why the possibility of entering into a treaty should not be foreclosed. The right choice for achieving our common goal will be not to select either one or the other but instead to move toward exploring these two perspectives simultaneously.

\section{VI \\ CONCLUSION}

The recent globalization of social economy and culture has yielded some favorable conditions for resolving these conflicts. The international lawyers, who are educated in multiple countries, qualified to practice in those countries, and actually practicing internationally, are developing an increasingly neutral legal culture. These international lawyers are more open-minded than the average practitioner, which will assist in overcoming parochial prejudice. The remarkable increase in the number of these international lawyers will play an important role in creating the cooperative spirit and the rules needed for an ideal resolution of international civil disputes. For these lawyers, the legal market is worldwide; therefore, the primary interest is no longer the expansion of one's own domestic market by broadening the international jurisdiction of one's own country. Instead, the focus can shift to smoothing procedural conflicts on an international level.

However, international judicial friction will not be eliminated by such trend in toto, even if mitigated. A more challenging task for us will be to search for a mixed procedural system enriched by international cross-fertilization. Each legal system in various legal families in the world should have something to contribute to the improvement of other systems. Each country has to innovate its own system by learning from each other. Such mutual enrichment should especially be encouraged between the common law family and the continental law family which tend to be in conflict. In this connection, it is an attractive idea to organize a new international expert forum for sounding out a possibility of harmonization among several legal families. 
